ARTICLE

\title{
Retrospective Analysis of Work From Home for Civil Servants During The Covid- 19 Pandemic
}

\author{
Gugun Geusan Akbar ${ }^{1^{*}}$, Nita Nurliawati ${ }^{2}$, Muchtar ${ }^{3}$, and Abdullah Ramdhani ${ }^{4}$ \\ 1,3,4 Faculty of Social and Political Sciences, University of Garut, Jl. Cimanuk No. 285 A Garut, \\ Indonesia \\ ${ }^{2}$ State Development Administration Study Program, Polytechnic LAN Bandung, Jl. Hayam Wuruk \\ No.34, Bandung City, Indonesia
}

How to cite: Akbar, Gugun G., Nurliawati, Nita., Muchtar., \& Ramdhani, Abdullah.(2021). Retrospective Analysis of Work from Home for Civil Servants during the Covid-19 Pandemic. Jurnal Borneo Administrator, 17(2), 183-204. https://doi.org/10.24258/jba.v17i2.811

\section{Article History \\ Received: 14 December 2020}

Accepted: 28 May 2021

\section{Keywords:}

Policy

Work from Home

Civil Servants

COVID-19

\begin{abstract}
The COVID-19 pandemic hitting Indonesia has created new habitual adaptations, including working from home for civil servants. This policy presents a new challenge, namely maintaining performance through achieving the effectiveness of working from home. The present study investigates the implementation of the work from home policy through Spearman's rank-order correlation analysis to examine the correlation between research variables. Furthermore, after the Kruskal-Wallis significant test, the Dunn-Bonferroni post hoc method was used to look for the differences between the factors affecting the effectiveness of working from home of the civil servants based on gender and age and education, and years of service. Data were collected through questionnaires to 437 civil servants from various government agencies, both central and regional. The study's findings indicate differences in the factors influencing the effectiveness of working from home and the skills required depending on gender, age, education, and years of service. The results also show that information technology support is not evenly distributed in implementing the work from home policy. The implication of this study suggests that the evaluation of the implementation of the work from home policy for the civil servants is beneficial for the government in considering sustainability and quality development in the future.
\end{abstract}

\section{A. INTRODUCTION}

The COVID-19 pandemic raises a crisis not only in the health sector, but also in various aspects of life. Those have implications for most of the world population as they need to adapt to life and work patterns (ILO \& OECD, 2020: 6). One of the steps in minimizing the worsening of the COVID-19 pandemic is the issuance of a large-scale social restriction (PSBB) policy. This policy leads to restrictions on certain population activities at a time and area to prevent the possible spread of disease or contamination (Fauzi, 2020: 175). One of the implications of implementing PSBB is the emergence of a policy of working from home or called work from home (WFH) for civil servants (PNS) and private-sector workers.

\footnotetext{
* Corresponding Author

Email: gugun.ga@fisip.uniga.ac.id
} 
For civil servants, this policy creates a complex situation where the demands of office work must be the same as the targets that have been set while managing personal and family life, which also requires an adaptation process in a pandemic atmosphere. This sudden change in the work environment has limited them in adapting to new work situations and practices (Dawis, 2000: 268). The phenomenon that emerged later showed that the COVID19 pandemic has permanently changed civil servants work in various sectors. This is proven by implementing the $W F H$ policy on them, which was previously impossible.

WFH has become an interesting phenomenon for many researchers in various countries and has been studied from objects, methods, and approaches. Several studies related to $W F H$ were conducted on employees in nine European countries. The results show that the ideal work culture strengthens the increase in family conflict. In this context, the ideal work culture is that employees have a high work ethic and tend to conflict with the expectations of other family members. When doing activities $W F H$, most family members often perceive being on vacation or leave and hope to be more involved in family activities, not focusing on completing office work like working in an office (van der Lippe \& Lippényi, 2020: 384; P \& Shahid, 2020: 3). Another research shows that in countries that emphasize individualism, lower power distance, and higher femininity, workers are more likely to be empowered when working at home (Ollo-López et al., 2020: 14). Research conducted by Raišien (2020) on employees through correlation analysis shows differences in the evaluation of factors that affect the efficiency of remote work and the quality required of remote workers, depending on gender, age, education, work experience, and work experience remotely. Although working at home provides various advantages, employees do not really like working at home (Raišiene et al., 2020: 19). The results of other studies also found that there are still many obstacles in the implementation of WFH, including culture (Ollo-López et al., 2020:12; Chudinovskikh \& Tonkih, 2020: 63), creativity (Naotunna \& Priyankarao, 2020: 365), and the information technology gap (Elldér, 2019: 13). Besides, working at home also does not guarantee a work-life balance (G-lvez et al., 2020: 16). The existence of these obstacles explains why the development of the implementation of working remotely or working from home in European countries is slow (Aguilera et al., 2016: 2; Eurofound, 2017: 57).

Besides research conducted in European countries, many studies on WFH have been conducted in Indonesia. Several studies show that the implementation of $W F H$ has positive and negative impacts. The positive impact is the finding of increased work productivity during WFH when conditions and situations are supportive (Simarmata, 2020:80; Wahyu \& Sa'id, 2020: 57). Other studies indicate a strong and positive relationship between WFH and work performance (Nasution \& Rosanti, 2020: 12; Ashal, 2020: 236). The negative impact of the implementation of WFH is mental workload (Gautama et al ., 2020: 87), dual role conflict (Hapsari, 2020: 42), work-life balance for women (Dua \& Hyronimus, 2020: 257).

This study aims to determine the difference in perceptions between male and female civil servants using the correlation analysis method as in the research of Raišien e et al. 1, 2020 by adding information technology variables to determine information technology support at the time of $W F H$ for civil servants in Indonesia. Knowledge of PNS perceptions of WFH is quite important considering that in the context of a pandemic, identifying and understanding PNS perceptions during the implementation of $W F H$ will help support the development of $W F H$ practices carried out by civil servants in particular and generally in the governance process. The research findings will be useful in the context closely related to post-PSBB policies and anticipate various potential crises concerning future civil servants' work. The research results are expected to provide concrete recommendations that can be followed up, especially for public organizations, as the input for future policies of $W F H$ so that it will become more efficient, effective, adaptive, and solutive. 


\section{B. LITERATURE REVIEW}

The conception of WFH cannot be separated from telework or working remotely, which is defined in two main dimensions, namely distance from conventional workplaces and use of information and communication technology (ICT) for work (Baruch, 2000: 45). Another opinion adds flexibility as one part of the definition to provide an overview of the balance between work and personal life (Ayoung \& Jumin, 2017: 154), or a variable proportion of working time spent in teleworking (Golden \& Gajendran, 2019: 11). However, the two viewpoints seem to differ in terms of the role that ICTs play in defining telework. The first point of view, the defining telework criteria, focuses on what exists "outside the conventional workplace" (Pérez et al., 2002: 775). ICT is seen as a means of staying in touch, communicating with others, and accessing one's professional activities to resolve distance and the workplace. It is different from the second approach, where ICT is a tool to communicate and, more importantly, a job reconfiguration. This perspective refers more to telework or virtual work, which implies restructuring the way work is done. In contrast, work is done remotely and often collaboratively using ICT (Baker et al., 2006: 421).

Based on the above conception, working remotely is often equated with telecommuting or 'telework'. The concept of 'telework' allows workers to complete tasks from home (Potter, 2003: 80). Through the development of information technology that is getting faster along with the birth of internet technology, also increasingly fierce business competition, more and more organizations are implementing the concept of working remotely (Asgari \& Jin, 2015: 1). Another opinion states that there are several types of work, including working with flexible hours (flexible schedule) and working remotely (telecommuting) (Heathfield, 2019: 1). Furthermore, the concept of 'telework' or 'telecommuting' is also broadly interpreted as that workers are allowed to work from different times and places of work with the conventional work system to balance the fulfilment of work and other worklife needs. Whether done from home or other locations outside the office, remote work is carried out freely that allows working from or outside the office all or part of the time (Mungkasa, 2020a: 130).

Although working remotely has various forms, in general, it can be categorized into three types. They are telecommuting or working at home, satellite office or working from a branch office near the home or satellite office, and mobile work or work anywhere outside the office as needed (Mungkasa, 2020b: 25). For civil servants, these three types can be used considering several arrangements in the policy. Under certain conditions working from home is carried out in shifts; work can also be done in other offices besides the main office and inflexible place and time. Like other workers, working remotely for civil servants has various benefits and obstacles during its implementation.

From various studies that have been conducted, there are factors related to WFH, which are individual characteristics, gender, age, education, and experience. Individual characteristics are very important to describe who wants and or who is suitable for teleworking (Bailey \& Kurland, 2002: 386). Gender has been identified as an influential factor (Loo \& Wang, 2018: 3; Sener \& Reeder, 2012: 1460; Singh et al., 2013: 380). Age is another factor associated with practice WFH (Sener \& Reeder, 2012: 1460; Singh et al., 2013: 384). Education level (Loo \& Wang, 2018: 5) and experience (Yen, 2000: 150) affect WFH.

\section{METHOD}

This study used a quantitative correlational approach to determine the differences in perceptions of male and female civil servants based on education level, age difference and length of service for positive and negative impacts, technological support, and individual 
readiness when carrying out $W F H$. This approach was adopted to photograph the relationship quantitatively between the investigated variables.

\section{Data Analysis}

To measure the relationship between research variables using Spearman's Rank-Order Correlation with the help of software SPSS version 20. Furthermore, the Post hoc DunnBonferroni method was carried out after the Kruskal-Wallis significant test. The post hoc Dunn-Bonferroni method was used to find differences in perceptions between male and female civil servants based on education level, age level, and length of service on the positive and negative impacts and the constraints of information technology and individual readiness when $W F H$.

\section{Research Instruments}

Data was obtained through a questionnaire divided into four parts: questions to find out the benefits or positive factors, obstacles or negative factors, the quality of individuals needed, and technological support when working from home. The research questionnaire was adapted from Mungkasa and Raišiene (Mungkasa, 2020b: 7; Raišiene et al., 2020: 20). All questionnaires used a Likert scale with points ranging from 1 (strongly disagree) to 5 (strongly agree).

The list of questions to examine the benefits or advantages of policy implementation consists of 11 questions, which aim to measure positive things in maintaining performance through the effectiveness of WFH. The reliability coefficient of Alpha Cronbach from the questionnaire is 0.818 . Then the questionnaire to determine the inhibiting factors that affect the effectiveness of WFH consists of 27 questions to measure the negative aspects of WFH. The reliability coefficient Alpha Cronbach from the questionnaire is 0.940 . The competencies required when doing work from home are measured by seven questions to describe the individual qualities needed when WFH. The reliability coefficient Alpha Cronbach from the questionnaire is 0.910. Meanwhile, the availability of technology to support policy implementation from home is measured by eight questions. The reliability coefficient Alpha Cronbach from the questionnaire is 0.653 .

\section{Characteristics of Respondents}

To explore the condition of civil servants while WFH and analyse the factors that influence the implementation of the policy, questionnaires were distributed to employees who work in central, provincial, and district/city government agencies. Although what is meant by the state civil apparatus includes civil servants (PNS) and contract-based government employees (PPPK), all respondents in this study only had the status of civil servants. Data collection was carried out on the 20th of the 25th of October, 2020, using Google Form. Information on the request for filling out the questionnaire is submitted through the Website, Facebook Fanpage and Instagram of State Civil Apparatus, and Whatsapp Groups. In total, 437 employees are willing to be respondents in this study. The study sample consisted of $61.8 \%(\mathrm{~N}=270)$ men and 38.26\% ( $\mathrm{N}=167)$ women, for more details, see Table 1 below.

The table describes the sociodemographic characteristics of the respondents studied. These characteristics consist of gender, age, education, and years of service, followed by the number according to these characteristics.

Furthermore, the researchers divided them into four age groups representing each generation, namely Generation Baby Boomers, Generation X, Generation Y, and Generation Millennials (Ng \& Lyon, 2018: 150). The age distribution of respondents is: Generation Baby Boomers 4.8\% ( $=21)$, Generation X 47.1\% $(\mathrm{N}=206)$, Generation $\mathrm{Y} 41.4 \%(\mathrm{~N}=$ $181)$, and Millennial Generation $64 \%(\mathrm{~N}=249)$. Based on education level, $11.2 \%(\mathrm{~N}=49)$ of 
respondents had a high school/vocational education and equivalent, $6.4 \%(\mathrm{~N}=28)$ had a diploma, $45.1 \%(\mathrm{~N}=197)$ had a bachelor's degree, $30.7 \%(\mathrm{~N}=134)$ had a master's degree, and $6.6 \%(\mathrm{~N}=29)$ had a doctorate. The respondents' tenure consisted of $37.3 \%(\mathrm{~N}=163)$ between 0-9 years, $41.6 \%(\mathrm{~N}=182)$ had 10-19 years of service, 9.8\% $(\mathrm{N}=43)$ were in the range of 20-29 years, and the remaining 11.2\% ( $\mathrm{N}=49)$ worked above 30-39 years. Respondents were informed about the study purpose, the nature of filling out the voluntary questionnaire, and the confidentiality of their responses.

Table 1. Characteristics of Respondents

\begin{tabular}{ccc}
\hline Variable & Description & $\mathrm{N}$ \\
\hline Gender & Man & 270 \\
& Woman & 167 \\
Age & $22-25($ Generation Millennial $)$ & 29 \\
& $26-40($ Generation Y $)$ & 181 \\
$41-55($ Generation X) & 206 \\
Education & Senior High School/Vocational High & 21 \\
& School & \\
& Diploma & 49 \\
& Bachelor & 28 \\
& Master & 197 \\
& Doctor & 134 \\
& & 29 \\
Years of service & $0-9$ Years & 163 \\
& $10-19$ Years & 182 \\
& $20-29$ Years & 43 \\
& $30-39$ Years & 49 \\
\hline
\end{tabular}

\section{RESULTS AND DISCUSSION}

The measurement results on the perception of male and female civil servants show similarities and differences, as shown in Table 2. The data show that the most positive thing about working from home for both men and women is independence in work arrangements.

Table 2 shows the results of calculating the correlation between gender, age, education level, and years of service and the positive impact of $W F H$ on the respondents. The calculation shows different results between the studied constructs.

Female civil servants are more likely to view working from home as a positive thing. However, in terms of independence, women show a perception that tends to be negative. It means that although the policy WFH is perceived as a positive thing, it cannot be denied that working together or in groups for female civil servants is more enjoyable. Meanwhile, male civil servants tend to show a more negative attitude towards implementing the work from home policy. It can be seen from their responses stating that working from home cannot eliminate unnecessary interactions, improve the ability to work independently, pay attention to health programs and eliminate the obligation to dress formally. Male employees perceive that $W F H$ is less likely to help eliminate unnecessary interactions between employees. For them, working in the office or at home, unnecessary interactions can both occur. The likelihood of unnecessary interactions occurring at home is relatively greater in the view of male employees. 
Table 2. Correlation of Sex, Age, Education Level and Years of Service with Positive Impact $W F H$

\begin{tabular}{|c|c|c|c|c|}
\hline Construct & Gender & Age & Education & Years of Service \\
\hline $\begin{array}{l}\text { Work arrangements are done } \\
\text { independently }\end{array}$ & $0.115^{*}$ & $-0.120 *$ & $0.116^{*}$ & $0.112^{*}$ \\
\hline More flexible working hours & 0.006 & $-0.262 * *$ & 0.003 & $0.213^{* *}$ \\
\hline More flexible workplace & -0.026 & $-0.175^{* *}$ & -0.016 & $0.150^{* *}$ \\
\hline Increase work motivation & -0.040 & $0.137 * *$ & 0.068 & -0.021 \\
\hline Work done individually & $-0.095^{*}$ & $-0.144 * *$ & 0.052 & $0.096^{*}$ \\
\hline $\begin{array}{l}\text { Balance between work and } \\
\text { personal life }\end{array}$ & 0.057 & $-0.123^{*}$ & 0.033 & $0.132^{* *}$ \\
\hline $\begin{array}{l}\text { Eliminate time to go to the } \\
\text { office }\end{array}$ & 0.043 & -0.074 & 0.041 & $0.099 *$ \\
\hline $\begin{array}{ll}\text { Eliminate } & \text { unnecessary } \\
\text { interactions } & \end{array}$ & $-0.184 * *$ & 0.084 & $-0.236 * *$ & $-0.116^{*}$ \\
\hline $\begin{array}{l}\text { Improve the ability to work } \\
\text { independently }\end{array}$ & $-0.111^{*}$ & -0.011 & -0.090 & $0.101^{*}$ \\
\hline $\begin{array}{l}\text { Eliminate the obligation to dress } \\
\text { formally }\end{array}$ & $-0.196 * *$ & -0.012 & 0.006 & -0.086 \\
\hline
\end{tabular}

The response of female civil servants who tend to view work that needs to be done independently is relevant to the research of Dua and Hyronimus (2020:257). Women have multiple roles that require them to prioritize and manage their time better than men. Women who are unable to balance work and family life in the WFH period will feel dissatisfied with their work and even stress because of the demands of the role that must be done at the same time (Dua \& Hyronimus, 2020:257). In women's perception, work and home life balance are directly related to social sustainability. The ultimate goal will remain unattainable if the balance problem is not resolved (G-lvez et al., 2020:16).

Regarding the negative response of male civil servants that WFH eliminates the obligation to dress formally, they tend to view work uniforms as an important issue. It is even possible that for male civil servants, the uniform is pride that shows their identity in family and society. Therefore, during $W F H$, wearing a civil servant work uniform may be a longing and a need for self-actualization.

The results of the analysis of the perceptions of female and male civil servants on the positive impact above are quite interesting, where the calculation results show that the respondents did not significantly feel the theoretically positive impact of WFH. In general, things that have a positive impact, such as flexibility of place, the flexibility of time, work motivation, the balance between work and personal life, and eliminating time to go to the office, are not significantly felt by civil servants. Table 3.

Furthermore, employee perceptions of the negative impact of $W F H$ can be seen in 
Table 3. Correlation of Gender, Age, Education Level and Years of Service with Negative Impact $W F H$

\begin{tabular}{|c|c|c|c|c|}
\hline Construct & Gender & Age & Education & Years of Service \\
\hline $\begin{array}{l}\text { Lack of face-to-face } \text { with } \\
\text { coworkers }\end{array}$ & 0.042 & -0.049 & -0.075 & -0.033 \\
\hline $\begin{array}{l}\text { Lack of face-to-face with } \\
\text { leadership }\end{array}$ & 0.048 & -0.057 & -0.034 & 0.062 \\
\hline $\begin{array}{l}\text { Establish boundaries for mutual } \\
\text { trust with coworkers }\end{array}$ & 0.066 & $-0.159 * *$ & $0.163^{* *}$ & $0.098^{*}$ \\
\hline $\begin{array}{l}\text { Establish boundaries for mutual } \\
\text { trust with superiors }\end{array}$ & -0.067 & 0.048 & 0.056 & 0.026 \\
\hline Lack of team spirit & 0.003 & 0.075 & $0.098 *$ & -0.042 \\
\hline $\begin{array}{l}\text { Raise excessive expectations } \\
\text { from superiors }\end{array}$ & $-0.118^{*}$ & $-0.116^{*}$ & 0.084 & $0.163 * *$ \\
\hline $\begin{array}{l}\text { Raise communication problems } \\
\text { with coworkers }\end{array}$ & $-0.208 * *$ & -0.061 & -0.032 & 0.053 \\
\hline $\begin{array}{l}\text { Access to information at work } \\
\text { becomes difficult }\end{array}$ & -0.043 & -0.056 & -0.041 & 0.083 \\
\hline $\begin{array}{l}\text { This leads to a lack of feedback } \\
\text { from both co-workers and } \\
\text { leaders }\end{array}$ & 0.051 & $0.120^{*}$ & 0.042 & $-0.110^{*}$ \\
\hline $\begin{array}{l}\text { Causing a blurring of } \\
\text { boundaries between work and } \\
\text { personal life }\end{array}$ & -0.029 & -0.034 & 0.069 & -0.031 \\
\hline $\begin{array}{l}\text { Getting interrupted by other } \\
\text { family members while doing } \\
\text { work }\end{array}$ & 0.048 & 0.055 & -0.022 & -0.010 \\
\hline $\begin{array}{l}\text { It causes overtime because the } \\
\text { leader is not able to estimate the } \\
\text { workload }\end{array}$ & $-0.167 * *$ & $-0.126 * *$ & 0.031 & $0.151^{*}$ \\
\hline $\begin{array}{l}\text { Leads to a lack of an inspiring } \\
\text { work atmosphere }\end{array}$ & 0.010 & $0.159^{* * *}$ & -0.043 & -0.065 \\
\hline $\begin{array}{l}\text { Create challenges related to self- } \\
\text { organization in following work } \\
\text { routines }\end{array}$ & -0.051 & 0.075 & $-0.141 * *$ & -0.035 \\
\hline $\begin{array}{l}\text { There is jealousy towards } \\
\text { people who get assignments } \\
W F H \text { while I have to work in } \\
\text { the office }\end{array}$ & $0.152 * *$ & 0.014 & $0.112^{*}$ & -0.026 \\
\hline $\begin{array}{l}\text { Causing important information } \\
\text { to be missed }\end{array}$ & -0.057 & $-0.125 * *$ & 0.084 & $0.199 * *$ \\
\hline Raising concerns about the lack & -0.013 & -0.035 & -0.029 & $0.162^{* *}$ \\
\hline
\end{tabular}
of appreciation and attention 
from the leadership on the results of my work adequately

Lack of means to show work results lead to career restrictions

This leads to an overload of information on the work to be done

Causes a decrease in the quality of work as a team

Causes the longer time to conduct work meetings

This leads to longer decision making

Causes communication to be out of sync and time consuming

Cause teamwork to focus more on communication than the task

Causes tension due to distribution of attention between work tasks and intense communication

Creates difficulty in identifying the beginning and end of several tasks being carried out simultaneously

Family members do not understand the concept of $\mathrm{WfH}$
$-0.087$
$-0.108^{*}$
$0.185^{* *}$
$0.173^{* *}$

0.002

$-0.038$

$-0.033$

$0.133^{* *}$

$-0.098 *$

0.023

0.017

$-0.002$

$-0.144 * *$

0.007

0.067

0.094*

$-0.078$

$0.157^{* *}$

0.004

$-0.080$

0.062

$-0,017$

0.050

0.021

$-0.181 * *$

$0, .36^{* *}$

$-0.025$

$-0.087$

$-0.206 * *$

$-0.063$

0.061

0.041

$-0.073$

$0.153^{* * *}$

$-0.015$

$-0.131 * *$

$-0,186^{* *}$

$0.113 *$

$-0.127 * *$

0.026

Source: Processed research results, ${ }^{*} p<0.05, * * p<0.01$

Table 3 describes the quantitative correlation between gender, age, education level, and years of service and its negative impact on $W F H$. Based on the respondents' responses, both female and male civil servants regarding the negative impact of WFH tend to have the same view. The negative impact that was most felt when the $W F H$ policy was implemented was excessive expectations from superiors. It means that their superiors seem to show the same expectations and even exceed the performance rather than working in the office or Work from Office (WfO). It is different from the results of studies in European countries where superiors do not give excessive burdens and expectations when WFH (Raišiene et al., 2020: 6). Whereas the situation of the COVID-19 pandemic, family health is the main priority of and various other variables that appear simultaneously in terms of complexity requires a capable adaptation process. There are also communication problems with coworkers. Direct face-to-face communication in the office is replaced by virtual communication with various limitations that also require a learning and adaptation process. Another interesting thing is the emergence of responses that the policy of working $W f H$ causes overtime because the leader cannot estimate the workload of each subordinate or member of the organization. It is similar to superiors in Japan, who tend to give additional workloads when employees work at home (Kazekami, 2020:16). 
The series of negative perceptions that are built can allegedly reduce the quality of work usually done in teams, causing the time needed to conduct work meetings to be longer. Furthermore, the negative perception obtained from the study results shows that both male and female civil servants view that the WFH policy implementation causes the work team to focus more on communication than completing tasks. Theoretically, one of the biggest challenges of working remotely is communication. Information technology reduces face-toface interaction, which is an important source of social interaction (Ammons \& Markham, 2004:231; Cooper \& Kurland, 2002:985; Wilson \& Greenhill, 2004:219). This is allegedly becoming the reason why civil servants have problems with communication. The awareness of the long-distance communication problem causes them to focus more on how they communicate. However, the emphasis on communication and the existence of communication barriers cause the completion of tasks to be disrupted. The distribution of attention between work tasks and intensive communication needs to be established tension within employees (Donnelly \& Proctor-Thomson, 2015:313). Besides, it is suspected that the problem will increase when family members do not understand the concept of WfH. Interaction with family is one thing that affects productivity when $W F H$, so productivity will be disrupted if the family does not understand this concept (Neufeld \& Fang, 2005:1047). Some family members can think that civil servants are on vacation or on leave which can lead to demands for various roles that must be played simultaneously. However, it turns out that male civil servants show more negative attitudes towards these factors than female civil servants. Meanwhile, female civil servants show more jealousy towards other employees who assigns to do $W f H$ while they need to work in the office.

Next, the research data on individual readiness when carrying out the work from the home policy can be seen in Table 4. Correlation analysis shows that good communication and strong personal responsibility are the most needed individual readiness. Female civil servants are more concerned with good communication skills and strong personal responsibility as qualities needed to carry out $\mathrm{WfH}$. Meanwhile, male civil servants showed a rejection of the personal leadership quality factor as a necessary thing when working from home. It means that male civil servants may expect a relatively stable work system compared to their leadership qualities.

Table 4. Correlation of Gender, Age, Education Level and Years of Services with Individual Readiness

\begin{tabular}{lcccc}
\hline \multicolumn{1}{c}{ Construct } & Gender & Age & Education & Years of Service \\
\hline Good time management skills & 0.059 & 0.012 & -0.094 & -0.029 \\
Digital literacy skills & -0.023 & 0.010 & -0.043 & -0.057 \\
Personal leadership qualities & $-0.101^{*}$ & $0.161^{* *}$ & -0.068 & -0.081 \\
Good communication skills & $0.111^{*}$ & $0.177^{* *}$ & -0.019 & $-0.135^{* *}$ \\
$\begin{array}{l}\text { Ability to engage and maintain a } \\
\text { commitment to the organization }\end{array}$ & 0.052 & 0.030 & $-0.173^{* *}$ & 0.012 \\
$\begin{array}{l}\text { Strong personal responsibility } \\
\text { Source: Process research resuls }\end{array}$ & $0.168^{* *}$ & 0.063 & -0.019 & -0.090 \\
\hline
\end{tabular}

Source: Processed research results, $* p<0.05, * * p<0.01$.

Table 4 shows the results of calculating the magnitude of the correlation between gender, age, education level, and years of service and individual readiness when carrying out WfH. 
Next are the results of research related to technological barriers, which can be seen in Table 5. Correlation analysis shows that both male and female civil servants agree that in terms of technological barriers, retrieving data and information from the office is no longer the biggest obstacle. The obstacle that arises is the internet quality that is insufficient to support the policy of $W F H$, which is in line with the results of previous research (Ashal, 2020:240; Nugroho \& Suswanta, 2020:230). The lack of technological support when working at home during the pandemic does not only occur in Indonesia, and the OECD notes limitations in various countries, especially in most African countries and developing countries (OECD, 2020:3).

Table 5. Correlation of Gender, Age, Education Level and Years of Service with Technological Barriers

\begin{tabular}{|c|c|c|c|c|}
\hline Construct & Gender & Age & Education & $\begin{array}{l}\text { Years of } \\
\text { Service }\end{array}$ \\
\hline $\begin{array}{l}\text { Retrieval of data and information from the } \\
\text { office online }\end{array}$ & $0.115^{*}$ & $\begin{array}{l}0.129 * \\
*\end{array}$ & $-0.139 * *$ & $-0.120 *$ \\
\hline $\begin{array}{l}\text { Internet quality is sufficient to support } \\
W f H\end{array}$ & $-0.101 *$ & -0.041 & $-0.136 * *$ & -0.020 \\
\hline $\begin{array}{l}\text { The quality of the device owned is } \\
\text { sufficient enough to do } W f H\end{array}$ & -0.057 & -0.001 & $-0.155^{* *}$ & -0.029 \\
\hline The office provides tools to carry out $\mathrm{WfH}$ & -0.091 & 0.008 & $-0.392 * *$ & -0.013 \\
\hline $\begin{array}{l}\text { Leaders can monitor work and result in } \\
\text { real-time when } W f H\end{array}$ & -0.065 & $\begin{array}{l}0.131 * \\
*\end{array}$ & $-0.174 * *$ & -0.074 \\
\hline $\begin{array}{l}\text { Technological developments and } \\
\text { adaptations in WfH can interfere with work } \\
\text { results }\end{array}$ & -0.072 & -0.025 & 0.063 & $0.094 *$ \\
\hline Reliance on technology inhibits $W f H$ & 0.015 & -0.060 & 0.001 & $0.113^{*}$ \\
\hline
\end{tabular}

Table 5 describes the results of calculating the magnitude of the correlation between gender, age, education level, years of service, and technological barriers when running $W F H$.

Regarding the relationship between the respondent's age and the positive and negative impact of WFH, the calculation results show a negative relationship between the respondent's age and the evaluation of factors that negatively affect the effectiveness of WFH. The analysis results show that the older generation tends to view working from home more negatively. At the same time, the younger generation is more concerned with the qualities needed to carry out work from homes, such as good communication and strong personal responsibility.

After measuring the relationship between the respondent's age and the positive and negative impact of $W F H$, the researcher analyzed the relationship between different intergenerational perspectives on the factors that affect the effectiveness of WFH. We carried out a follow-up test using the post hoc Dunn-Bonferroni method with the Kruskal-Wallis test, as shown in Table 6. 
Table 6. Correlation of Age with Impact WFH

\begin{tabular}{|c|c|c|c|c|c|}
\hline Construct & Generation & $\mathrm{N}$ & Mean Rank & $X^{2}$ & $p$ \\
\hline $\begin{array}{l}\text { Establish boundaries for } \\
\text { mutual trust with co- } \\
\text { workers }\end{array}$ & $\begin{array}{c}\text { Baby Boomers } \\
\mathrm{X} \\
\mathrm{Y} \\
\text { Millennials }\end{array}$ & $\begin{array}{c}29 \\
181 \\
206 \\
21\end{array}$ & $\begin{array}{l}231.86 \\
238.59 \\
208.51 \\
158.35\end{array}$ & 13.438 & 0.004 \\
\hline $\begin{array}{lr}\text { Raise } & \text { excessive } \\
\text { expectations } & \text { from } \\
\text { superiors } & \end{array}$ & $\begin{array}{c}\text { Baby Boomers } \\
\text { X } \\
\text { Y } \\
\text { Millennials }\end{array}$ & $\begin{array}{c}29 \\
181 \\
206 \\
21\end{array}$ & $\begin{array}{l}332.82 \\
208.53 \\
223.48 \\
148.33\end{array}$ & 33.204 & 0.000 \\
\hline $\begin{array}{l}\text { This leads to a lack of } \\
\text { feedback from both co- } \\
\text { workers and superiors }\end{array}$ & $\begin{array}{c}\text { Baby Boomers } \\
\mathrm{X} \\
\mathrm{Y} \\
\text { Millennials }\end{array}$ & $\begin{array}{c}29 \\
181 \\
206 \\
21\end{array}$ & $\begin{array}{l}264.22 \\
187.49 \\
242.01 \\
208.44\end{array}$ & 24.206 & 0.000 \\
\hline $\begin{array}{l}\text { It causes overtime } \\
\text { because the leader is not } \\
\text { able to estimate the } \\
\text { workload }\end{array}$ & $\begin{array}{c}\text { Baby Boomers } \\
\mathrm{X} \\
\mathrm{Y} \\
\text { Millennials }\end{array}$ & $\begin{array}{c}29 \\
181 \\
206 \\
21\end{array}$ & $\begin{array}{l}279.52 \\
222.00 \\
217.72 \\
153.00\end{array}$ & 14.655 & 0.002 \\
\hline $\begin{array}{l}\text { This leads to a lack of an } \\
\text { inspiring } \\
\begin{array}{ll}\text { atmosphere } & \text { work } \\
\end{array}\end{array}$ & $\begin{array}{c}\text { Baby Boomers } \\
\text { X } \\
\text { Y } \\
\text { Millennials }\end{array}$ & $\begin{array}{c}29 \\
181 \\
206 \\
21\end{array}$ & $\begin{array}{l}259.60 \\
188.47 \\
231.90 \\
283.78\end{array}$ & 24.696 & 0.000 \\
\hline $\begin{array}{l}\text { Causing important } \\
\text { information to be missed }\end{array}$ & $\begin{array}{c}\text { Baby Boomers } \\
\mathrm{X} \\
\mathrm{Y} \\
\text { Millennials }\end{array}$ & $\begin{array}{c}29 \\
181 \\
206 \\
21\end{array}$ & $\begin{array}{l}269.74 \\
225.88 \\
209.56 \\
199.02\end{array}$ & 8.883 & 0.032 \\
\hline $\begin{array}{l}\text { Lack of means to show } \\
\text { work results lead to } \\
\text { career restrictions }\end{array}$ & $\begin{array}{c}\text { Baby Boomers } \\
\mathrm{X} \\
\mathrm{Y} \\
\text { Millennials }\end{array}$ & $\begin{array}{c}29 \\
181 \\
206 \\
21\end{array}$ & $\begin{array}{l}269,92 \\
218,67 \\
222,44 \\
147,65\end{array}$ & 17.207 & 0.001 \\
\hline $\begin{array}{l}\text { This leads to longer } \\
\text { decision making }\end{array}$ & $\begin{array}{c}\text { Baby Boomers } \\
\mathrm{X} \\
\mathrm{Y} \\
\text { Millennials }\end{array}$ & $\begin{array}{c}29 \\
181 \\
206 \\
21\end{array}$ & $\begin{array}{l}200,22 \\
197,06 \\
238,79 \\
229,31\end{array}$ & 12.875 & 0.005 \\
\hline $\begin{array}{l}\text { Cause teamwork to focus } \\
\text { more on communication } \\
\text { than the task }\end{array}$ & $\begin{array}{c}\text { Baby Boomers } \\
\mathrm{X} \\
\mathrm{Y} \\
\text { Millennials }\end{array}$ & $\begin{array}{c}29 \\
181 \\
206 \\
21\end{array}$ & $\begin{array}{l}240,40 \\
192,75 \\
235,84 \\
243,09\end{array}$ & 14.396 & 0.002 \\
\hline $\begin{array}{l}\text { Creates difficulty in } \\
\text { identifying the beginning } \\
\text { and end of several tasks } \\
\text { being carried out } \\
\text { simultaneously }\end{array}$ & $\begin{array}{c}\text { Baby Boomers } \\
\mathrm{X} \\
\mathrm{Y} \\
\text { Millennials }\end{array}$ & $\begin{array}{c}29 \\
181 \\
206 \\
21\end{array}$ & $\begin{array}{l}220,58 \\
202,35 \\
218,62 \\
330,26\end{array}$ & 27.149 & 0.000 \\
\hline $\begin{array}{l}\text { Family members do not } \\
\text { understand the concept } \\
\text { of } W f H\end{array}$ & $\begin{array}{c}\text { Baby Boomers } \\
\text { X } \\
\text { Y }\end{array}$ & & $\begin{array}{l}222,08 \\
206,97 \\
217,28\end{array}$ & 17.054 & 0.001 \\
\hline
\end{tabular}




\begin{tabular}{ccc}
\hline & & \\
\hline & & 308,65 \\
& 29 & \\
& 181 & \\
& 206 & \\
& 21 & \\
\hline
\end{tabular}

Source: Processed research results

Table 6 describes the calculation results of the magnitude of the correlation between age and its impact on $W F H$. The calculation results show that there is a difference in the number of correlations between the generations studied. The test results show that compared to all other generations, the Baby Boomers generation felt that working from home had raised excessive expectations from their superiors for their performance. This generation also feels a lack of feedback and the emergence of overtime work because the superior cannot estimate the workload. Besides, for the Baby Boomers generation, the WFH policy often creates feelings of concern about missing important information and even fears of career restrictions. In general, the various negative views of the Baby Boomers generation towards WFH are in line with the results of previous studies. Namely, when $W F H$ employees aged 50 years and over experienced increased mental burden, which was caused by an increase in the internalization of information technology, changes in work communication patterns, and work systems (Gautama et al., 2020: 88).

The results of another analysis show that compared to all other generations, it turns out that Generation Y more often feels that working from home causes the decision-making process to take longer. Meanwhile, when compared to the generation Millennial, the generation Y more often feels there are limits to mutual trust with colleagues. That is, the more seniors, the more decrease the trust level of co-workers they have. The age can be seen based on generation categorization.

The researcher examines the relationship between the respondent's education and all research variables in the next analysis stage. As shown in Table 8, the study results show that respondents who have a higher level of education tend to have independence when doing WfH. However, they have a perception of career restrictions. Besides, they tend to feel boundaries to trust each other with co-workers. This indicates their reduced enthusiasm when working in a team.

In contrast, measurements indicate that employees with lower levels of education tend to believe that the WFH policy eliminates unnecessary interactions. They also feel that the implementation of this policy makes them pay more attention to health programs and has challenges related to self-organization in following work routines. Furthermore, they tend to have barriers, namely family members who do not understand the concept of working from home. Similarly, regarding the individual qualities needed when $W F H$, respondents with relatively lower education will encourage the ability to engage in various work tasks and maintain a commitment to the organization.

Continuing the above analysis, a post hoc test Kruskal-Wallis was conducted to determine the relationship between differences in education level about positive and negative factors and individual quality needs when applying for. As shown in Table 8, the analysis results show that respondents with high school education lack independence in carrying out their work compared to those with higher education. Besides, compared to all other educational groups, the respondents with a high school education considered the ability to build trust with colleagues less important. They tend to have good prejudice and do not experience the assumption of excessive expectations from superiors or career restrictions. Even respondents with high school education do not attach the importance of good time management skills. Regarding technology support, they also have the same response as 
respondents at other education levels. Their problem is also about the quality of internet connections when they work from home.

The results of the analysis of respondents' responses with a diploma level of education show a higher level of concern than other levels of education in terms of good time management skills. This includes the ability to engage and maintain a commitment to the organization. However, about technology support when working from home, respondents with a diploma level of education believe that the quality of the internet connection is adequate to support their work, and the office has provided devices to conduct work activities from home. Respondents with a master's level of education felt a blurred line between work and personal life compared to other respondents. This group is also more likely to feel jealous of people who get assignments $W F H$ when they have to work in the office.

The result of the analysis of the responses from the next respondent group is the doctoral education level. The results of the study show that civil servants in this group can work independently. In addition, they can build trust with co-workers, work with a team spirit, and be concerned about information compared to respondents at different educational levels. The analysis results show that respondents with a higher level of education have a higher level of readiness than other levels of education. This is in line with the results of studies in other countries, which indicate that workers with higher levels of education are better prepared when working at home. This is because complex knowledge and experience are required to operate information technology and make decisions (Drucker \& Khattak, 2003 2000:112; Carillo et al ., 2020:12) . For more details, table 7 summarizes the results of calculating the quantitative correlation.

Table 7. Correlation of Education Level with Impact WFH

\begin{tabular}{|c|c|c|c|c|c|}
\hline Construct & Education & $\mathrm{N}$ & Mean Rank & $X^{2}$ & $p$ \\
\hline \multirow{5}{*}{$\begin{array}{l}\text { Work arrangements are made } \\
\text { independently }\end{array}$} & High School & 49 & 194.73 & \multirow{5}{*}{8.530} & \multirow{5}{*}{00.074} \\
\hline & Diploma & 21 & 172.67 & & \\
\hline & Bachelor Degree & 207 & 220.92 & & \\
\hline & Master Degree & 131 & 228.37 & & \\
\hline & Doctoral Degree & 29 & 237.57 & & \\
\hline \multirow{5}{*}{$\begin{array}{l}\text { Eliminate } \\
\text { interactions }\end{array}$} & High School & 49 & 253.34 & \multirow{5}{*}{30.512} & \multirow{5}{*}{0.000} \\
\hline & Diploma & 21 & 314.29 & & \\
\hline & Bachelor Degree & 207 & 224.86 & & \\
\hline & Master Degree & 131 & 190.32 & & \\
\hline & Doctoral Degree & 29 & 179.71 & & \\
\hline \multirow{5}{*}{$\begin{array}{l}\text { Establish boundaries for } \\
\text { mutual trust with co-workers }\end{array}$} & High School & 49 & 181.60 & \multirow{5}{*}{13.309} & \multirow{5}{*}{0.010} \\
\hline & Diploma & 21 & 223.12 & & \\
\hline & Bachelor Degree & 207 & 208.19 & & \\
\hline & Master Degree & 131 & 243.20 & & \\
\hline & Doctoral Degree & 29 & 247.09 & & \\
\hline \multirow{5}{*}{ Lack of team spirit } & High School & 49 & 213.80 & \multirow{5}{*}{11.403} & \multirow{5}{*}{0.022} \\
\hline & Diploma & 21 & 247.14 & & \\
\hline & Bachelor Degree & 207 & 202.81 & & \\
\hline & Master Degree & 131 & 232.03 & & \\
\hline & Doctoral Degree & 29 & 264.09 & & \\
\hline \multirow{6}{*}{$\begin{array}{l}\text { Raise excessive expectations } \\
\text { from superiors }\end{array}$} & High School & 49 & 183.53 & \multirow{5}{*}{19.780} & \multirow{5}{*}{0.001} \\
\hline & Diploma & 21 & 304.69 & & \\
\hline & Bachelor Degree & 207 & 206.57 & & \\
\hline & Master Degree & 131 & 234.43 & & \\
\hline & Doctoral Degree & 29 & 235.95 & & \\
\hline & & & & 9.132 & 0.058 \\
\hline
\end{tabular}




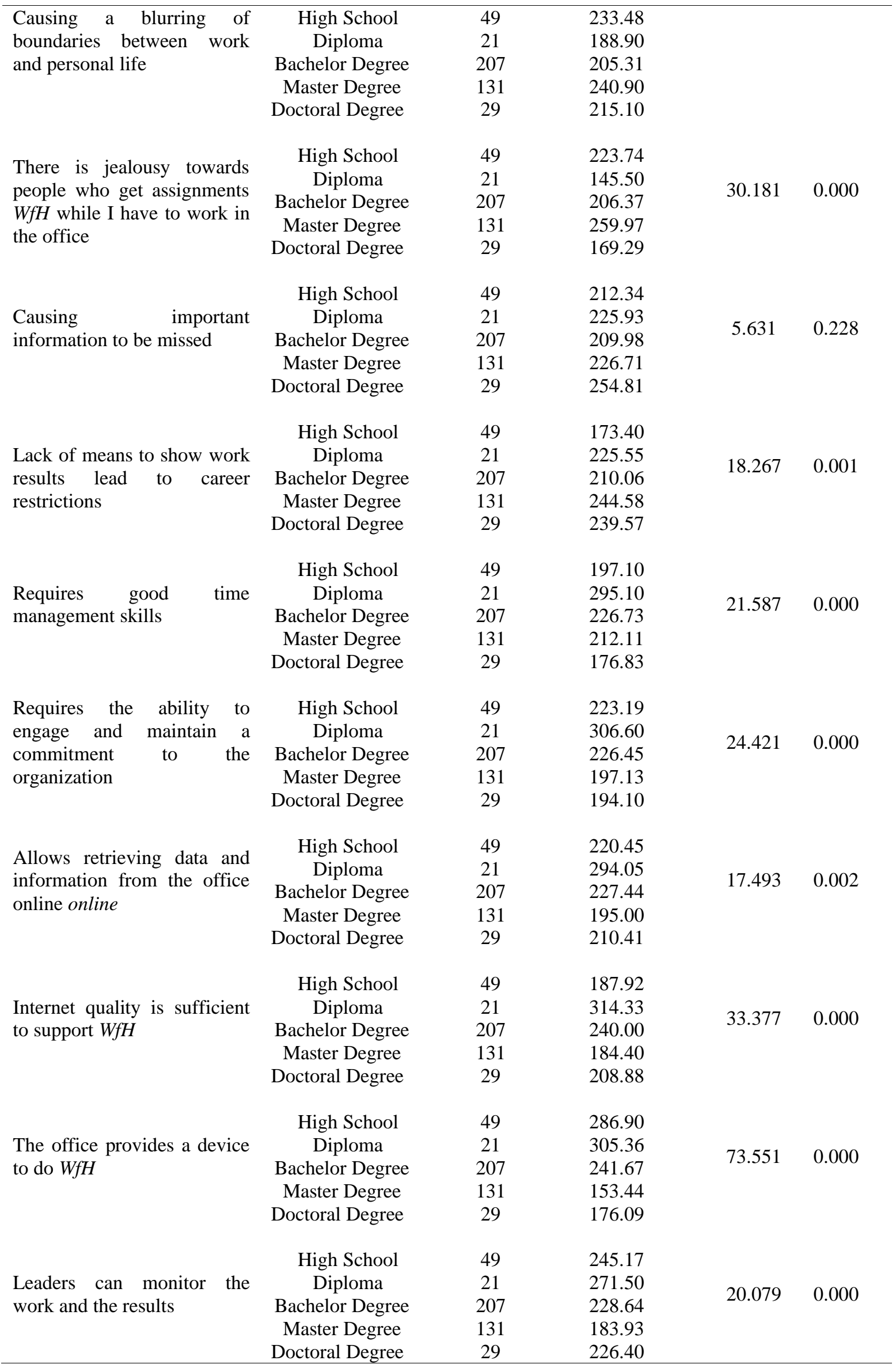

Source: Processed research results 
Table 7 describes calculating results the magnitude of the correlation between the level of education and the impact of $W F H$. As shown in the table, the results show the difference in responses between levels of education measured as described in the previous paragraph.

Subsequent analyses, as described in table 8, relate to differences in service life and their correlation with the application of WFH. The analysis results using the post hoc test Kruskal-Wallis show that compared to respondents with other tenures, respondents who have a working period of 0-9 years tend to see the individual qualities needed are personal leadership and good communication. Meanwhile, respondents with 30-39 years of service see that strong responsibility is required when $W F H$. Regarding the technical support aspect, compared to respondents with other tenures, respondents with a working period of 0-9 years felt that daily work could still be done by taking data and information from the office virtually when working from home. However, respondents aged 20-29 years feel that technological developments and adaptations in working from home activities influence the work results.

Table 8. Correlation of Working Period with Individual Readiness
Years of

\begin{tabular}{|c|c|c|c|c|c|}
\hline Construct & $\begin{array}{l}\text { Years of } \\
\text { service }\end{array}$ & $\mathrm{N}$ & Mean Rank & $X^{2}$ & $p$ \\
\hline $\begin{array}{l}\text { Requires personal } \\
\text { leadership qualities }\end{array}$ & $\begin{array}{c}9 \text { Years } \\
10-19 \text { Years } \\
20-29 \text { Years } \\
30-39 \text { Years }\end{array}$ & $\begin{array}{c}163 \\
182 \\
43 \\
49\end{array}$ & $\begin{array}{l}230.87 \\
212.90 \\
189.08 \\
228.44\end{array}$ & 7.725 & 0.052 \\
\hline $\begin{array}{l}\text { Requires good } \\
\text { communication skills }\end{array}$ & $\begin{array}{c}9 \text { Years } \\
10-19 \text { Years } \\
20-29 \text { Years } \\
30-39 \text { Years }\end{array}$ & $\begin{array}{c}163 \\
182 \\
43 \\
49\end{array}$ & $\begin{array}{l}232.01 \\
224.08 \\
169.07 \\
200.65\end{array}$ & 13.429 & 0.004 \\
\hline $\begin{array}{l}\text { Requires strong personal } \\
\text { responsibility }\end{array}$ & $\begin{array}{c}9 \text { Years } \\
10-19 \text { Years } \\
20-29 \text { Years } \\
30-39 \text { Years }\end{array}$ & $\begin{array}{c}163 \\
182 \\
43 \\
49\end{array}$ & $\begin{array}{l}235.04 \\
210.26 \\
158, .57 \\
251.14\end{array}$ & 23.445 & 0.000 \\
\hline $\begin{array}{l}\text { Allows retrieving data and } \\
\text { information from the office } \\
\text { online }\end{array}$ & $\begin{array}{c}9 \text { Years } \\
10-19 \text { Years } \\
20-29 \text { Years } \\
30-39 \text { Years }\end{array}$ & $\begin{array}{c}163 \\
182 \\
43 \\
49\end{array}$ & $\begin{array}{l}234.81 \\
215.02 \\
187.29 \\
209.00\end{array}$ & 7.618 & 0.055 \\
\hline $\begin{array}{l}\text { Technological } \\
\text { developments and } \\
\text { adaptations in WfH can } \\
\text { interfere with work results }\end{array}$ & $\begin{array}{c}0-9 \text { Years } \\
10-19 \text { Years } \\
20-29 \text { Years } \\
30-39 \text { Years }\end{array}$ & $\begin{array}{c}163 \\
182 \\
43 \\
49\end{array}$ & $\begin{array}{l}208.17 \\
217.90 \\
240.79 \\
239.98\end{array}$ & 4.369 & 0.004 \\
\hline $\begin{array}{l}\text { Dependence on technology } \\
\text { inhibits activity } W f H\end{array}$ & $\begin{array}{c}0-9 \text { Years } \\
10-19 \text { Years } \\
20-29 \text { Years } \\
30-39 \text { Years }\end{array}$ & $\begin{array}{c}163 \\
182 \\
43 \\
49\end{array}$ & $\begin{array}{l}200.72 \\
229.17 \\
219.38 \\
241.68\end{array}$ & 7.016 & 0.071 \\
\hline
\end{tabular}

Meanwhile, respondents with 30-39 years of service feel that dependence on technology hinders $W f H$. This phenomenon can be explained because respondents with shorter years are 
the younger generation more adaptive to using information technology. Indeed, they were born in that era. In contrast, the older generation considers working at home requiring skills to utilize information technology and take time to learn it to be less adaptive to information technology (Drucker \& Khattak, 2000:111). The complete quantitative correlation measurement results can be seen in Table 8 .

Table 8 above describes the results of calculating the magnitude of the correlation between years of service and individual readiness to apply WFH. As shown in the table, the results show differences between workers with a certain length of service and their readiness to implement the policy $W F H$.

Overall, referring to tables 2 to 8 , the results of the data analysis indicate that the implementation of WFH allows civil servants to work more independently. However, by comparing respondents' answers in various variables, the analysis shows different positive and negative aspects that influence respondents' performance when WFH (Donnelly \& Proctor-Thomson, 2015:113; Aguilera et al., 2016; G-lvez et al., 2020:10). The research results from a gender perspective indicate that female civil servants tend to view independence more negatively when carrying out work from home activities. Female civil servants value more opportunities to work from home to ensure that their health is further improved. Meanwhile, male civil servants tend not to overthink the health aspect when they do $W F H$.

In general, male civil servants perceive that working from home negatively than female civil servants. This is suspected because changes in the dynamics of work relations, perceptions of role conflict, and changing communication patterns play a greater role in male civil servants. Furthermore, they can be 'open' in stating communication problems with coworkers, decreased quality of work carried out as a team, and other family members who interfere when they work from home. When carrying out WfH that male civil servants highlighted, several other negative aspects were excessive expectations from superiors, the time required to complete the work became longer, and the work team focused more on communication than completing tasks. Finally, male civil servants were statistically more likely to face the challenge of emerging tension due to the distribution of attention between work tasks and intense communication compared to female civil servants.

In contrast to male civil servants, female civil servants are more jealous of employees who carry out $W F H$ while going to the office. The results also show that female civil servants are statistically more confident that good communication skills and strong personal responsibility are important factors when carrying out WFH. Regarding technical support, both male and female civil servants agree that working from home allows them to retrieve data and information online. They also agree that the quality of the internet is not sufficient to support the optimization of WFH. However, when viewed from the level of education, employees with diploma education tend to feel that the internet's quality is sufficient to support working from home.

From a gender perspective, male civil servants consider their careers to be more successful when they can work 'normally' in the office. This result comes from their assumption that $W F H$ brings a negative factor for the continuity of their work. Furthermore, male civil servants feel their performance will decrease and feel a 'threat' to their careers when carrying out $W F H$.

The relationship between respondents' age and research variables shows that the older generation tends to view the policy WFH negatively. Meanwhile, the younger generation tends to see working from home requiring more special skills and competencies than working in an office. The older generation (baby boomers and generation $\mathrm{X}$ ) mostly feel that employers have excessive expectations of their work when carrying out activities WFH. They also feel a lack of feedback, an additional obligation for overtime due to incompetent 
managers estimating workloads and worry about missing important information and possible career restrictions. Also, generation baby boomers and generation $\mathrm{X}$ often feel there is a limit to mutual trust with colleagues when doing $W F H$.

The younger generation, namely generation $\mathrm{Y}$ and generation millennial, statistically tend to benefit from the implementation of $W F H$ compared to the negative aspects. Thus, this study has shown that for civil servants, especially generation baby boomers and generation $\mathrm{X}$, WFH has greater challenges than generation $\mathrm{Y}$ and generation millennials. In terms of technology, the last generation is certainly more ready and able to use technology because they were born at that time. While the older generation, baby boomers and generation $\mathrm{X}$, are more comfortable working in a conventional way where they can mingle together in the office.

A study of the impact of education on performance $W F H$ shows that respondents with higher education have independence when doing work from home activities. However, they also feel there are obstacles when doing work at home. This finding is in line with civil servants who have a lower level of education. They also tend to have challenges related to self-organization in following work routines and obstacles in family members who do not understand the concept of $W F H$.

Analysis of the individual qualities needed when $W F H$, statistically respondents with lower education tend to be less likely to have many barriers related to trust, excessive expectations, and less worried about career restrictions. They also do not attach much importance to time management skills. It can be explained because the level of work with lower education, work type, work with a difficult level, work complexity, and the demand for skills in the job is not very high.

The study results show similarities between this study and previous research conducted by Raišien (2020). In general, women feel more comfortable working from home than men. The older generation tends to emphasize the disadvantages of telework, while the younger generation emphasizes that teleworking requires special skills and competencies compared to working in an office. For the older generation, working from home poses a higher challenge than the younger generation. From the similarity of the research results, it can be concluded that the perception of working from home for both private and government employees has similarities.

Some findings that can be extracted from the study results show that the profiles of civil servants who are most prepared and able to maintain good performance and productivity when working at home are male and female civil servants who belong to the millennial generation with a high level of education. This finding implies a fairly high expectation for the implementation of working from home in the future, given the current acceptance of civil servants, which requires age and education restrictions.

Another research finding is that although in some conditions, civil servants who work at home can still maintain their performance and productivity as the results of previous studies, in general, there are still conditions that hinder the achievement of such performance and productivity. Internal conditions considered an obstacle are career restrictions, disturbed communication relationships with co-workers, and an unsupportive work environment at home. Meanwhile, external obstacles are high demands from superiors which can be pressure at work and lack of technological support. This study's findings complement previous research that identified the factors influencing $W F H$, especially in government employees in Indonesia.

\section{E. CONCLUSION}

In general, this study shows that there are differences in the assessment from the perspective of gender, age, education, and years of service on the benefits, advantages or 
positive sides and disadvantages or negative aspects, the quality needed when working and technology support when implementing the work from home policy. The study results indicate a decrease in performance in civil servants with a lower level of education and short years of service. Also, during the implementation of large-scale social restrictions (PSBB), the work activities of civil servants are carried out in a WFH pattern. This causes communication problems with colleagues to be more common than before the implementation of the PSBB.

\section{Recommendation}

Recommendations on the policy $W F H$ for stakeholders are, first, the need for support and understanding from superiors towards subordinates when they work from home. Second, maintaining and creating a good communication situation and the need for socialization on understanding the concept of $W F H$ for the community and civil servants. Third, about information and communication technology for the success of the long-distance work pattern that has been accepted as part of adopting new habits, the government must pay more attention to the readiness of supporting facilities and infrastructure and its technological infrastructure.

\section{Limitation}

We recognize the limitations of the results of this study. Geographically, this research is not sufficiently representative to represent various regions in Indonesia that have different characteristics. Another limitation is related to a comprehensive study that has not been carried out on several findings, such as trust, communication, independence, and other results that are different from the results of previous studies. This opens up opportunities for further research on matters that have not been studied in depth. However, the results of this study are expected to contribute to the consideration of a better implementation of $W F H$ in the future, helping to encourage the creation of higher performance and work motivation for civil servants in particular, which ultimately has an impact on the effectiveness of the implementation of $\mathrm{WFH}$ for wider organizational life.

\section{Acknowledgements}

We want to thank all those who have contributed to this research, especially the admin Whatsapp Group in various government agencies and the social media admin of the state civil apparatus who assisted in distributing research questionnaires.

\section{Contributorship}

Gugun Geusan Akbar: compiling research and initiating study designs.

Nita Nurliawati: assisting the implementation and compiling the analysis.

Muchtar: assisting with implementation and compiling analysis.

Abdullah Ramdhani: conducted the primary statistical analysis.

All authors contributed to refining the study protocol and approving the final manuscript.

\section{REFERENCES}

Aguilera, A., Lethiais, V., Rallet, A., \& Proulhac, L. (2016). Home-based telework in France: Characteristics, barriers and perspectives. Transportation Research Part A: Policy and Practice, 92, 1-11. https://doi.org/10.1016/j.tra.2016.06.021

Ammons, S. ., \& Markham, W. . (2004). Working at home: experiences of skilled whitecollar workers. Sociological Spectrum, 24(2), 191-238.

Asgari, H., \& Jin, X. (2015). Toward a comprehensive telecommuting analysis framework: Setting the conceptual outline. Transportation Research Record, 2496(November), 1-9. 
https://doi.org/10.3141/2496-01

Ashal, R. A. (2020). Pengaruh Work From Home terhadap Kinerja Aparatur Sipil Negara di Kantor Imigrasi Kelas I Khusus TPI Medan. Jurnal Ilmiah Kebijakan Hukum, 14(2), 223. https://doi.org/10.30641/kebijakan.2020.v14.223-242

Ayoung, S., \& Jumin, L. (2017). Understanding teleworkers' technostress and its influence on job satisfaction. Internet Research, 27(1), 140-159. https://doi.org/10.1108/IntR-062015-0181

Bailey, Di. E., \& Kurland, N. B. (2002). A review of telework research: findings, new directions, and lessons for the study of modern work. British Journal of Anaesthesia, 89(5), 707-710. https://doi.org/10.1093/bja/89.5.707

Baker, P. M. A., Moon, N. W., \& Ward, A. C. (2006). Virtual exclusion and telework: Barriers and opportunities of technocentric workplace accommodation policy. Work, 27, 421-430.

Baruch, Y. (2000). Teleworking: benefits and pitfalls as perceived by professionals and managers. New Technology, Work and Employment (Print), 15(1), 34-49//.

Carillo, K., Cachat-Rosset, G., Marsan, J., Saba, T., \& Klarsfeld, A. (2020). Adjusting to epidemic-induced telework: empirical insights from teleworkers in France. European Journal of Information Systems, 00(00), 1-20. https://doi.org/10.1080/0960085X.2020.1829512

Chudinovskikh, M., \& Tonkikh, N. (2020). Telework in BRICS: Legal, Gender and Cultural Aspects. BRICS Law Journal, 7(4), 45-66. https://doi.org/10.21684/2412-2343-2020-74-45-66

Cooper, C. ., \& Kurland, N. B. (2002). Telecommuting, professional isolation, and employee development in public and private organisations. Journal of Occupational and Environmental Medicine, 36(9), 983-988.

Dawis, R. V. (2000). Work adjustment theory. In Encyclopedia of psychology, Vol. 8. (pp. 268-269). Oxford University Press. https://doi.org/10.1037/10523-114

Donnelly, N., \& Proctor-Thomson, S. B. (2015). Disrupted work: Home-based teleworking (HbTW) in the aftermath of a natural disaster. New Technology, Work and Employment, 30(1), 47-61. https://doi.org/10.1111/ntwe.12040

Drucker, J., \& Khattak, A. J. (2000). Propensity to work from home: Modeling results from the 1995 nationwide personal transportation survey. Transportation Research Record, 1706, 108-117. https://doi.org/10.3141/1706-13

Dua, M. H. C., \& Hyronimus. (2020). Pengaruh Work From Home Terhadap Work-Life Balance Pekerja Perempuan Di Kota Ende. Jurnal Ilmiah Manajemen Bisnis Dan Inovasi Universitas Sam Ratulangi, 7(2), 247-258.

Elldér, E. (2019). Who is eligible for telework? Exploring the fast-growing acceptance of and ability to telework in Sweden, 2005-2006 to 2011-2014. Social Sciences, 8(7). https://doi.org/10.3390/SOCSCI8070200

Eurofound. (2017). Working anytime, anywhere: The effects on the world of work. https://www.eurofound.europa.eu/publications/report/2017/working-anytime-anywherethe-effects-on-the-world-of-work

Fauzi, A. (2020). Implementasi Pembatasan Sosial Berskala Penanganan Pandemi COVID19. Jurnal Ilmu Administrasi Negara, 16(1), 174-178.

G-lvez, A., Tirado, F., \& Mart-nez, M. J. s. (2020). Work-life balance, organisations and social sustainability: Analysing female telework in Spain. Sustainability (Switzerland), 12(9), 1-21. https://doi.org/10.3390/SU12093567

Gautama, B. H., Fadhilah, I. D., \& Wibowo, A. (2020). Analysis of Implementation Work From Home on Employees Mental Workload in Customs and Excise Office of Tanjung Priok. 4(1), 1-19. 
Golden, T. D., \& Gajendran, R. S. (2019). Unpacking the Role of a Telecommuter's Job in Their Performance: Examining Job Complexity, Problem Solving, Interdependence, and Social Support. Journal of Business and Psychology, 34(1), 55-69. https://doi.org/10.1007/s10869-018-9530-4

Hapsari, I. (2020). Konflik Peran Ganda Dan Kesejahteraan Psikologis Pekerja Yang Menjalani Work From Home Pasca Pandemi COVID-19. Jurnal Psikologi, 13(1), 3745. https://doi.org/10.35760/psi.2020.v13i1.2623

Heathfield, S. M. (2019). Working With a Flexible Schedule. https://www.thebalancecareers.com/flexible-schedule-1918130

ILO, \& OECD. (2020). The impact of the COVID-19 pandemic on jobs and incomes in G20 economies. $\quad 46 . \quad$ https://www.ilo.org/wcmsp5/groups/public/---dgreports/--cabinet/documents/publication/wcms_756331.pdf

Kazekami, S. (2020). Mechanisms to improve labor productivity by performing telework. Telecommunications Policy, 44(2), 101868. https://doi.org/10.1016/j.telpol.2019.101868

Loo, B. P. Y., \& Wang, B. (2018). Factors associated with home-based e-working and eshopping in Nanjing, China. Transportation, 45(2), 365-384. https://doi.org/10.1007/s11116-017-9792-0

Mungkasa, O. (2020a). Bekerja dari Rumah (Working From Home/WFH): Menuju Tatanan Baru Era Pandemi COVID 19. Jurnal Perencanaan Pembangunan: The Indonesian Journal of Development Planning, 4(2), 126-150. https://doi.org/10.36574/jpp.v4i2.119

Mungkasa, O. (2020b). Bekerja Jarak Jauh (Telecommuting): Konsep, Penerapan dan Pembelajaran. Bappenas Working Papers, 3(1), 1-32. https://doi.org/10.47266/bwp.v3i1.52

Naotunna, N. P. G. S. I., \& Priyankara, H. P. R. (2020). The impact of telework on creativity of professional employees in Sri Lanka: Componential and social cognitive theoretical views. International Journal of Mobile Learning and Organisation, 14(3), 357-369. https://doi.org/10.1504/IJMLO.2020.108228

Nasution, I., \& Rosanti, R. (2020). Pengaruh Bekerja Dari Rumah (Work From Home) Terhadap Kinerja Karyawan Bpkp. Jurnal Ilmiah Akuntansi Budgeting, 1(1), 9-14.

Neufeld, D. J., \& Fang, Y. (2005). Individual, social and situational determinants of telecommuter productivity. Information and Management, 42(7), 1037-1049. https://doi.org/10.1016/j.im.2004.12.001

Ng, E. S., \& Lyon, S. T. (2018). Generational Career Shifts, How Matures, Boomers, Gen Xers, and Millennials View Work. Internet Research, 27(1), 140-159. https://doi.org/10.1108/IntR-06-2015-0181

Nugroho, M. F., \& Suswanta. (2020). Kendala Pelaksanaan dan Upaya Penanganan Work From Home/WFH di Bappeda Kabupaten Gunung Kidul. 17(2), 221-241.

OECD. (2020). Teleworking during the COVID-19 pandemic and beyond. https://read.oecdilibrary.org/view/?ref=135_135250-u15liwp4jd\&title=Productivity-gains-fromteleworking-in-the-post-COVID-19-era

Ollo-López, A., Goñi-Legaz, S., \& Erro-Garcés, A. (2020). Home-based telework: usefulness and facilitators. International Journal of Manpower. https://doi.org/10.1108/IJM-022020-0062

P, S., \& Shahid, M. (2020). Work from home during COVID-19: Employees perception and experiences Dr. Shareena P Mahammad Shahid *. Gjra - Global Journal for Research Analysis, 9(5), 7-10.

Pérez, M. P., Sánchez, A. M., \& De Luis Carnicer, M. P. (2002). Benefits and barriers of telework: Perception differences of human resources managers according to company's operations strategy. Technovation, 22(12), 775-783. https://doi.org/10.1016/S01664972(01)00069-4 
Potter, E. E. (2003). Telecommuting: The future of work, corporate culture, and American society. Journal of Labor Research, 24(1), 73-84. https://doi.org/10.1007/s12122-0031030-1

Raišiene, A. G., Rapuano, V., Varkulevičiute, K., \& Stachová, K. (2020). Working from home-Who is happy? A survey of Lithuania's employees during the COVID-19 $\begin{array}{llll}\text { quarantine } & \text { period. }\end{array}$ https://doi.org/10.3390/su12135332

Sener, I. N., \& Reeder, P. R. (2012). An examination of behavioral linkages across ICT choice dimensions: Copula modeling of telecommuting and teleshopping choice behavior. Environment and Planning A, 44(6), 1459-1478. https://doi.org/10.1068/a44436

Simarmata, R. M. (2020). Pengaruh Work From Home Terhadap Produktivitas Dosen Politeknik Negeri Ambon. Intelektiva: Jurnal Ekonomi, Sosial Dan Humaniora, 02(01), 73-82.

Singh, P., Paleti, R., Jenkins, S., \& Bhat, C. R. (2013). On modeling telecommuting behavior: Option, choice, and frequency. Transportation, 40(2), 373-396. https://doi.org/10.1007/s11116-012-9429-2

van der Lippe, T., \& Lippényi, Z. (2020). Beyond Formal Access: Organizational Context, Working From Home, and Work-Family Conflict of Men and Women in European Workplaces. Social Indicators Research, 151(2), 383-402. https://doi.org/10.1007/s11205-018-1993-1

Wahyu, A. M., \& Sa'id, M. (2020). Produktivitas Selama Work From Home: Sebuah Analisis Psikologi Sosial. Jurnal Kependudukan Indonesia, 2902, 53. https://doi.org/10.14203/jki.v0i0.570

Wilson, M., \& Greenhill, A. (2004). Gender and teleworking identities in the risk society: a research agenda. New Technology, Work and Employment, 19(3), 207-221.

Yen, J. R. (2000). Interpreting employee telecommuting adoption: An economics perspective. Transportation, 27(1), 149-164. https://doi.org/10.1023/A:1005200513201 
